\title{
Functional classification of artificial alluvial ponds driven by connectivity with the river: Consequences for restoration
}

\author{
Sophie Guillon ${ }^{\mathrm{a}, *}$, Maxine Thorel ${ }^{\mathrm{b}}$, Nicolas Flipo ${ }^{\mathrm{a}}$, Benjamin Oursel ${ }^{\mathrm{b}}$, Cécile Claret $^{\mathrm{b}}$, \\ Stéphanie Fayolle ${ }^{\mathrm{b}}$, Céline Bertrand ${ }^{\mathrm{b}}$, Bianca Rapple ${ }^{\mathrm{c}}$, Hervé Piegay ${ }^{\mathrm{c}}$, Jean-Michel Olivier ${ }^{\mathrm{d}}$, \\ Antonin Vienney ${ }^{\mathrm{d}}$, Pierre Marmonier ${ }^{\mathrm{d}}$, Evelyne Franquet ${ }^{\mathrm{b}}$ \\ ${ }^{a}$ MINES ParisTech, PSL Research University, Centre de Géosciences, 77300 Fontainebleau, France \\ ${ }^{\mathrm{b}}$ Aix Marseille Univ, Univ Avignon, CNRS, IRD, IMBE, Marseille, France \\ ${ }^{\mathrm{c}}$ ENS Lyon, UMR 5600 EVS, 69342 Lyon Cedex 07, France \\ ${ }^{\mathrm{d}}$ Univ Lyon, Université Claude Bernard Lyon 1, CNRS, ENTPE, UMR5023 LEHNA, F-69622 Villeurbanne, France
}

\begin{abstract}
A B S T R A C T
Chemical and biological functioning of artificial wetlands and lakes in alluvial plains is investigated based on the example of small artificial ponds located within dike fields along the Rhône River (France). The objective is to identify the diversity of metabolism in these artificial aquatic ecosystems and to propose a functional classification linked to the connectivity with the river. A comprehensive characterization of chemical and biological parameters in six shallow ponds was conducted, along with 4-month continuous monitoring of temperature and dissolved oxygen concentration, both in the sub-surface and at depth. Metabolism intensity is quantified using the diel oxygen method. Multivariate analysis of chemical and biological characteristics is performed to identify the functional heterogeneity between the ponds, which is shown to be consistent with the intensity of primary production (GPP) and ecosystem respiration (ER). Some ponds are permanently connected to the river, like backwater, and are very turbid, because of suspended matter and the presence of phytoplankton. The oxygenation is limited to the surface layer with anoxia rapidly building up at the bottom due to an intense ER. Ponds that are rarely connected become eutrophic with large concentration of phytoplankton and large GPP and ER values. Anoxia and even denitrification occur close to the bottom sediment. Finally, in the ponds with intermediate degree of connection with the river, macrophytes grow in clear water with limited amount of phytoplankton, resulting in a gradient of GPP and ER values, controlled by nutrient availability. Rehabilitation of various connection patterns with the river is thus crucial to maintain a functional diversity in large river alluvial plains.
\end{abstract}

\section{Introduction}

Wetlands services were widely discussed in the Millennium Ecosystem Assessment (2005) that highlights their role in provision of habitats for plants and animals (Gibbs, 2000; Hansson et al., 2005), improvement of water quality (Cheng and Basu, 2017) and sequestration of carbon (Lane et al., 2017), even if calculation of carbon budget in wetlands remains difficult. While the River Continuum Concept shows that large rivers are mainly dominated by respiration and hence a source of $\mathrm{CO}_{2}$ (Vannote et al., 1980), alluvial wetlands can be net sinks or sources of $\mathrm{CO}_{2}$ (Jeppesen et al., 2016; Lane et al., 2017, Mitsch et al., 2013; Moore et al., 1998; Preiner et al., 2008, Welti et al., 2012, Whiting and Chanton, 2001). From a seasonal point of view, lateral exchanges between the river and its floodplain during floods allow rapid inputs and recycling of nutrients and organic matter, thereby resulting in high productivity in the alluvial plains as well as in the river, provided they are connected (Flood Pulse Concept, Junk et al., 1989, Junk, 2005).

Despite these important roles, wetlands are decreasing worldwide (Davidson, 2014), especially in alluvial plains, and need consistent restoration plans (Erwin et al., 2017; Paillex et al., 2009; Tockner and Stanford, 2002) taking into account diversity of habitats for biodiversity and diversity of connections for fluxes of matter and nutrients (Castella et al., 2015, Koontz et al., 2016, Pont et al., 2017). These plans must result in a restoration of functional diversity at the alluvial plain scale (Español et al., 2015). Artificial wetlands constructed along 
several large European rivers during the 19th century are unique water bodies that must be taken into account in restoration plans (Franquet et al., 1995; Thorel et al., 2018). Dike fields (also called groyne fields) are fairly common infrastructures created along large rivers for flood and inundation management and to promote channel erosion for navigation. If they have been mainly terrestrialised over the last centuries, some of them remain as ponds. Because navigation now mainly occurs in large artificial waterways, those dikes built at the end of the 19th century have lost their functional utility. In Europe, there is thus a large program aiming to remove these dikes to restore lateral erosion during floods, sediments and nutrients inputs to the alluvial plain (Pont et al., 2017, Thorel et al., 2018) and to promote lateral floodplain's habitat dynamics. Such restoration programs with dikes removal and restored connectivity were already been conducted, for example in the Mississippi alluvial plain (Koontz et al., 2016) and proved to increase the productivity of forested riparian wetlands. Then there is an urgent need to understand and quantify the impacts of the dikes on productivity, sediment and organic matter budgets, not only in forested wetlands but also in aquatic environments.

In addition to increasing productivity, restoration plans also aim at increasing habitat diversity. However the contribution of the artificial ponds to functional diversity of alluvial plains is still not so well known. They are characterized by shallow depth, large depth to surface area ratio, relative young age, and appear to be prone to eutrophication, with large intensity of both ecosystem respiration (ER) and gross primary production (GPP).

Calculation of metabolism in such artificial shallow water bodies in alluvial plains is necessary to better understand their functioning (López-Archilla et al., 2004). Various methods have been used to quantify metabolism in aquatic ecosystems (Reeder and Binion, 2001; Staehr et al., 2010), with various spatial and temporal resolutions. Methods based on the diurnal variations of dissolved $\mathrm{O}_{2}$ were first introduced by (Odum, 1956) and gave access to in situ metabolism. The diel oxygen method is now widely used to calculate temporal dynamics of metabolism in rivers or lakes (Escoffier et al., 2018; Needoba et al., 2012).

The first aim of this work is to describe the functional diversity of artificial alluvial ponds based on biological and chemical characteristics, and establish a functional classification. As connectivity matters for biodiversity in natural alluvial wetlands (Amoros and Bornette, 2002), and because hydrology is considered as one of the most important factor driving wetland functions (Mitsch and Gossilink (2000); Cronk and Mitsch, 1994), we expect a large functional diversity of these artificial ponds linked to hydraulic connectivity (water exchanges with the main channel).

The second aim is to calculate metabolism with the diel oxygen method based on high resolution oxygen measurement in both shallow and deep layers. We expected weak stratification because of shallow depths (Ford et al., 2002), with significant productivity and oxygen reaching the bottom sediment.

Finally, we compared chemical and biological classification of these artificial wetlands with metabolism measurements. We hypothesized convergence between these two functional approaches (López-Archilla et al., 2004) to propose strategies for restoration plans (Thorel et al., 2018).

\section{Experimental site}

At the end of the 19th century, river regulation was conducted on the Rhône River (France), with building of longitudinal and herringbone submersible dikes, delimiting dike fields locally called "casiers Girardon" (Fig. 1). This was initially intended to promote a fixed deep single-bed channel for navigation and to store overbank fine sediments to induce dike fields terrestrialisation. In the middle of the 20th century, the main river channel was diverted to a series of parallel canals to power hydroelectric stations (Fig. 1). The former sections, called the
"Old Rhône", are bypassed and most of the times only convey a residual minimum. Several dike fields are present all along this bypassed section, called the "Old Rhône". In these bypassed reaches, most of the dike fields were progressively terrestrialised and even forested due to water level drop and sediment filling, and are now disconnected from the main river channel. Few of them remain as ponds connected to the river with various degrees of water exchanges.

Six such water bodies were chosen and instrumented on the Old Rhône at Péage-de-Roussillon ( $45^{\circ} 20^{\prime} \mathrm{N}, 4^{\circ} 45^{\prime} \mathrm{E}$ ), located $50 \mathrm{~km}$ South of Lyon (France). They are referred to as $\mathrm{C} 1$ to $\mathrm{C} 4$ on the right bank of the river, C5 and C6 on the left bank (Fig. 1). The ponds have an average depth ranging from 0.7 to $2.3 \mathrm{~m}$, for surface areas ranging from 1369 to $2890 \mathrm{~m} 2$ (Table 1), resulting in a large depth to surface area ratio compared to natural lakes and ponds. Aerial images and orthophoto analysis, coupled with study of historical maps allows calculation of these areas together with the percentage of open water and terrestrial habitats (Table 1).

During low flow, a minimum discharge of $50-125 \mathrm{~m}^{3} \mathrm{~s}^{-1}$ is maintained in the by-passed section at Péage-de-Roussillon, depending on the season (CNR, pers. comm.). When the maximum capacity of power plant is reached during high flow (e.g., $1600 \mathrm{~m}^{3} \mathrm{~s}^{-1}$ ), the rest of the flow is diverted towards the by-passed section, leading to the submersion of the dikes depending on flood intensity and dike elevation, resulting in a wide range of ecosystem functioning (Nicolas and Pont, 1997).

\section{Materials and methods}

\subsection{Hydraulic connectivity indexes}

Two approaches were used to determine the degree of hydraulic connectivity between each pond and the river.

Firstly, the long profiles of the dike elevation, obtained from LIDAR data derived DEM (From IGN) (Supplement Fig. S1), were compared to the water level in the Old Rhône for a reference minimum flow of $100 \mathrm{~m}^{3} \mathrm{~s}^{-1}$. An index of connectivity was calculated based on the statistics of discharge in the Old Rhône (Džubáková et al., 2015). For C5 and C6, part or the dike was below the water level at a flow of $100 \mathrm{~m}^{3}$ $\mathrm{s}^{-1}$, and thus these ponds were always connected to the river by surficial water, leading to the maximum value of the index, namely 1 .

Secondly, differences between the temperature measured continuously in the ponds (see below 3.3) and the temperature measured in the river were calculated to estimate hydraulic connectivity. The difference was reduced to zero when river water entered the pond above or through the dike. For each dike field, the sum of temperature differences was calculated and normalized by the length of the time series to give a second hydraulic connectivity index.

\subsection{Biological and chemical characterization}

A comprehensive characterization of biological and chemical functioning of the water bodies was conducted based on two surveys in June and September 2014. For each pond, three points were sampled as replicates. For each point, transparency was measured through Secchi depth, expressed in percentage of the total depth $\left(Z_{\text {secchi }} / Z\right)$.

Water was sampled with a horizontal 2L Niskin bottle at 1.5 times the Secchi depth, or a maximum of $1 \mathrm{~m}$ above the bottom of the pond. Half of the sample was filtered on glass fiber filters (Whatman GFF, $0.7 \mu \mathrm{m}$ ), that were calcinated during $4 \mathrm{~h}$ at $450^{\circ} \mathrm{C}$. Filtered water was stored in a HPDE bottle maintained at $-18^{\circ} \mathrm{C}$ until measurement of dissolved ions (including $\mathrm{PO}_{4}{ }^{3-}, \mathrm{NO}_{3}{ }^{-}$and $\mathrm{NH}_{4}{ }^{+}$) by ionic chromatography (METROHM, 930 Compact IC Flex and 863 Compact Autosampler).

On the unfiltered part of the water sample, concentration of chlorophyll $a$ (Chl a) was measured by spectrometry. The remaining sample was fixed with formaldehyde and sub-sampled $(25 \mathrm{~mL})$ for 

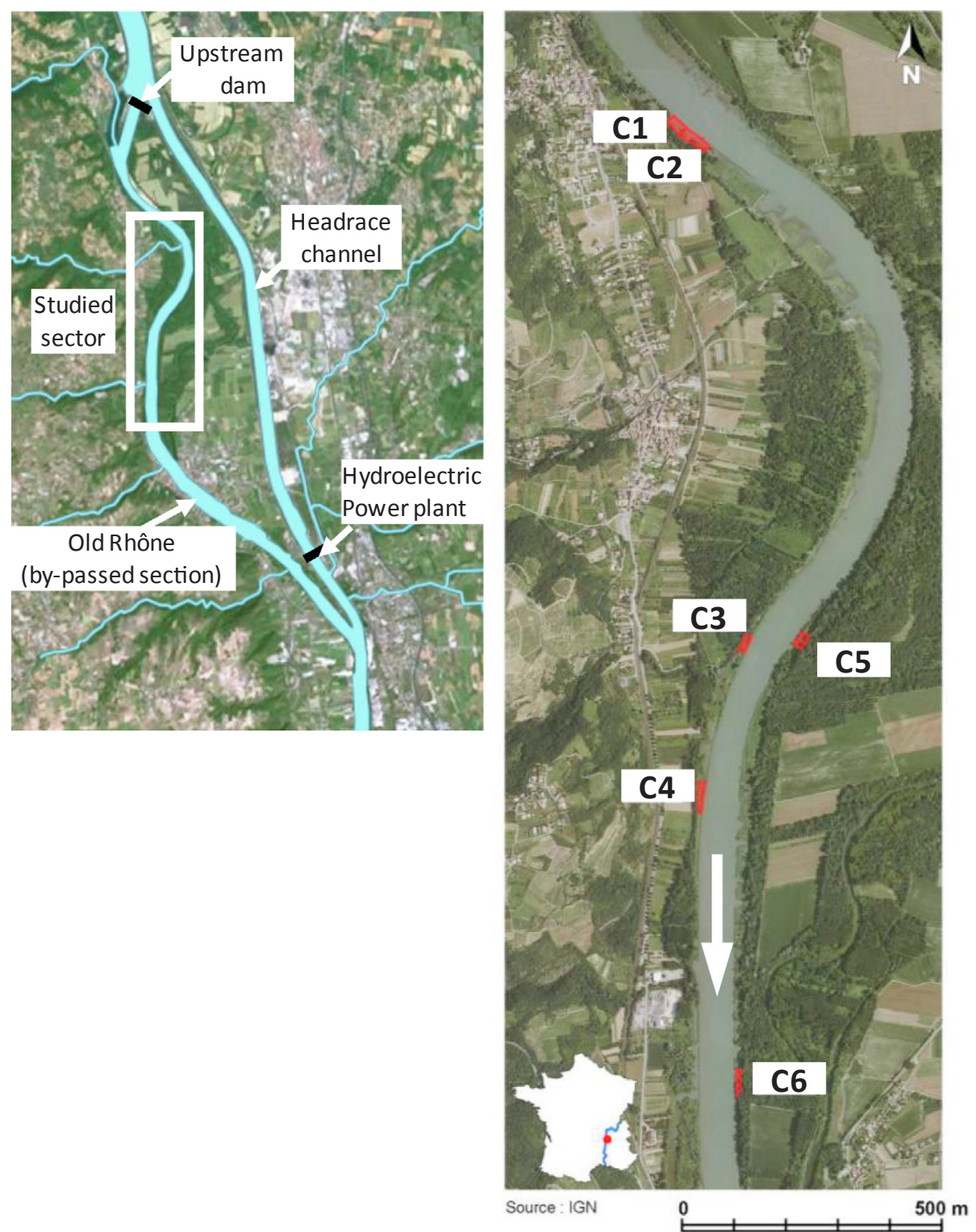

Fig. 1. Location of studied sector on the Old Rhône (left), and of the six studied ponds (C1-C6) within dike fields of the Old Rhône river at Péage-de-Roussillon (right). The river is flowing to the South. Maps source: IGN (https://www.geoportail.gouv.fr).

Table 1

Location and physical characteristics of the six ponds.

\begin{tabular}{|c|c|c|c|c|c|}
\hline $\begin{array}{l}\text { Dike } \\
\text { field }\end{array}$ & $\begin{array}{l}\text { Depth } \\
\text { (m) }\end{array}$ & $\begin{array}{l}\text { Area } \\
\left(\mathrm{m}^{2}\right)\end{array}$ & $\begin{array}{l}\text { Latitude } \\
45^{\circ} \mathrm{N}\end{array}$ & $\begin{array}{l}\text { Longitude } \\
4^{\circ} \mathrm{E}\end{array}$ & $\begin{array}{l}\text { Terrestrialisation of the initial dike } \\
\text { field } \\
(\%)\end{array}$ \\
\hline C1 & 1.8 & 2890 & 21.767 & 45.517 & 64 \\
\hline $\mathrm{C} 2$ & 2.3 & 1369 & 21.731 & 45.588 & 93 \\
\hline C3 & 1.4 & 1470 & 20.666 & 45.713 & 87 \\
\hline $\mathrm{C} 4$ & 1.2 & 2000 & 20.394 & 45.614 & 55 \\
\hline C5 & 2.2 & 2100 & 20.711 & 45.909 & 19 \\
\hline C6 & 0.7 & 2700 & 19.87 & 45.726 & 76 \\
\hline
\end{tabular}

* See Section 3.1 for more details.

phytoplankton identification (Olympus IX51 inverted phase contrast microscope) and expressed in number of cells per liter of water (Utermohl, 1958). The dominant groups of phytoplankton were defined for each sample. The presence of macrophytes in the ponds was determined qualitatively (absence, presence, large development).

Sediment was sampled using an Ekman grab sampler, then stored in
$150 \mathrm{~mL}$ HPDE bottles at $4^{\circ} \mathrm{C}$ for $24 \mathrm{~h}$. The supernatant was removed. A subsample of sediment was grinded. Potential activity of microbes in the sediment was measured based on the hydrolysis of fluoresceine diacetate (FDA activity) (Battin, 1997; Fontvieille et al., 1992; Mermillod-Blondin et al., 2013). The remaining sediment was frozen at $-18^{\circ} \mathrm{C}$, lyophilized and then sieved at $2 \mathrm{~mm}$. Organic matter (\%OM sed) concentration was obtained by loss on ignition after a $4 \mathrm{~h}$ calcination at $550{ }^{\circ} \mathrm{C}$. Total nitrogen was measured by elemental analyzer on one aliquot, while organic carbon was measured on another aliquot after reaction with sulfuric acid. The rate $\mathrm{C}_{\text {org }} / \mathrm{N}_{\text {tot }}$ was calculated $\left(\mathrm{C}_{\text {org }} /\right.$ $\mathrm{N}_{\text {tot }}$ sed).

To generate a functional classification of the ponds, a Multiple Correspondence Analysis (MCA) (Tenenhaus and Young, 1985) was performed on 9 qualitative and quantitative variables (data are summarized in Supplement Table S1). $\mathrm{NH}_{4}{ }^{+}$was excluded because it was only measured during the first survey. Chl a was also excluded because of its significant correlation with the number of cells. For each variable, the range of measured values was divided in 2-4 classes for the MCA analysis, to account for the variability of each variable. 


\subsection{High frequency monitoring of temperature and dissolved oxygen}

Water temperature and dissolved oxygen concentration were continuously monitored with HOBO sensors (U26 Dissolved Oxygen, U22 Water Temperature), both $20 \mathrm{~cm}$ below the surface and $20 \mathrm{~cm}$ above the bottom of the 6 ponds. Monitoring was conducted with a $30 \mathrm{~min}$ time step from 22nd July to 24th November 2014. For C2, the monitoring period started on 15th September 2014, for a total duration of 2 months. The changes of water levels in the ponds were not monitored, and were assumed negligible considering the range of flow rate in the Rhône river during the monitoring period. Wind speed measured at $10 \mathrm{~m}$ height with a $1 \mathrm{~h}$ time step was obtained from a weather station close to the study site (Albon, data from Météo France).

\subsection{Quantification of metabolism with two-layer diel oxygen method}

The analysis of the continuous time series of dissolved oxygen and temperature allowed the quantification of GPP (Gross Primary Production) and ER (Ecosystem Respiration) in both the surface and bottom layers, by the mean of the diel oxygen method (Escoffier et al., 2018; Needoba et al., 2012; Odum, 1956). As the ponds showed vertical stratification of temperature and oxygen concentration, the diel oxygen method was modified by taking into account two layers: surface and bottom (Fig. 2). The exchange flux between both layers, driven by the oxygen concentration gradient, was neglected following (Coloso et al., 2008).

For the surface layer, the budget of dissolved oxygen was calculated at a daily time scale, taking into account oxygen production by photosynthesis during the day, oxygen consumption by respiration during both day and night, and exchange flux at the water-atmosphere interface depending on the deviation from oxygen saturation. The dissolved oxygen concentration $\left[\mathrm{O}_{2}\right]$ (in $\mathrm{mg} \mathrm{m}^{-3}$ ) was thus driven by the following equation, from (Needoba et al., 2012):

$Z \cdot \frac{d\left[O_{2}\right]}{d t}=G P P(t)+E R(t)+k_{\text {rea }} \cdot\left\{\left[O_{2}\right]_{\text {sat }}(T)-\left[O_{2}\right](t)\right\}$

where $\mathrm{dO}_{2} / \mathrm{dt}$ is the time derivative of the measured oxygen concentration (in $\mathrm{mg} \mathrm{m}^{-3} \mathrm{day}^{-1}$ ), GPP the primary production (in $\mathrm{mg} \mathrm{m}^{-2}$ day $^{-1}$ ), ER the consumption by ecosystem respiration (in $\mathrm{mg} \mathrm{m}^{-2}$ day $^{-1}$ ), $\mathrm{k}_{\text {rea }}$ the re-aeration constant (in $\mathrm{m} \mathrm{day}^{-1}$ ), $\left[\mathrm{O}_{2}\right]_{\text {sat }}$ saturated oxygen concentration (in $\mathrm{mg} \mathrm{m}^{-3}$ ) at temperature $\mathrm{T}$, and $\mathrm{Z}$ the depth of the considered waterbody (in $\mathrm{m}$ ). Negative oxygen fluxes correspond to consumption or export of oxygen, while positive fluxes correspond to production or import.

The re-aeration coefficient at the water-atmosphere interface depends on wind velocity, temperature and gas type. Here we used the equation given in (Cole and Caraco, 1998) for low wind speed conditions in lakes:

$k_{600}=0.4968+0.0516 \cdot V_{\text {wind }}{ }^{1.17}$

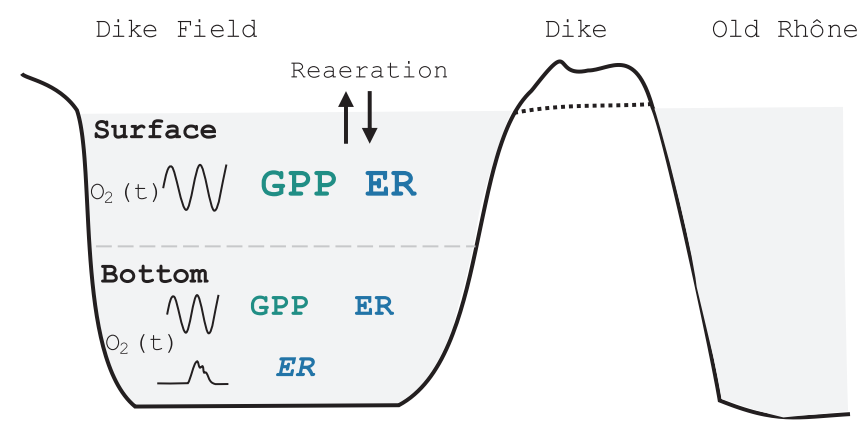

Fig. 2. Layout of a pond within a dike field and of the two-layer model used for the quantification of metabolism. The model calculates GPP and ER in both layers, and the re-aeration flux at the water-atmosphere interface. where $\mathrm{k}_{600}$ is in $\mathrm{m} \mathrm{day}^{-1}$ and $\mathrm{V}_{\text {wind }}$ is the wind velocity at $10 \mathrm{~m}$ height (in $\mathrm{m} \mathrm{s}^{-1}$ ). The re-aeration coefficient $\mathrm{k}_{\text {rea }}$ (in $\mathrm{m} \mathrm{day}^{-1}$ ) was then calculated by:

$k_{\text {rea }}=k_{600} \cdot\left(\frac{\operatorname{Sc}\left(T, O_{2}\right)}{600}\right)^{-0.67}$

where the Schmidt number for oxygen $\mathrm{Sc}\left(\mathrm{T}, \mathrm{O}_{2}\right)$ was calculated following (Wanninkhof, 1992) as a function of water temperature (in ${ }^{\circ} \mathrm{C}$ ):

$\operatorname{Sc}\left(T, O_{2}\right)=1911.1-118.11 \cdot T+3.4527 \cdot T^{2}-0.041320 \cdot T^{3}$

For water of low salinity and at limited altitude, the solubility of oxygen $\left[\mathrm{O}_{2}\right]_{\text {sat }}\left(\right.$ in $\mathrm{mg} \mathrm{L}^{-1}$ ) is a function of water temperature $\mathrm{T}$ (in ${ }^{\circ} \mathrm{C}$ ), as given by (Cox, 2003):

$\left[O_{2}\right]_{\text {sat }}(T)=14.652-0.41022 \cdot T+0.007991 \cdot T^{2}-7.7774 \cdot 10^{-5} \cdot T^{3}$

During the night, there is no photosynthetic activity $\left(\mathrm{GPP}_{\text {night }}=0\right)$. The re-aeration flux is calculated, and the only unknown flux remaining in Eq. (1) is $\mathrm{ER}_{\text {night }}$. Derivative of dissolved oxygen concentration during the night thus allowed calculating daily average respiration. During the day, the re-aeration flux was similarly calculated, ER was taken from the previous and following nights, and the time derivative of oxygen concentration thus allowed the calculation of the daily GPP. The main limitation of the diel oxygen method was to neglect the autotrophic respiration occurring during the day in addition to night respiration, but that cannot be constrained from oxygen measurements.

For the diel oxygen method, sunset and sunrise times were needed to define the beginning and end of photosynthesis activity for each day. As there was no data available for solar radiation at the study site, sunset and sunrise times were calculated from astronomical parameters using the NOAA-ESRL tool (http://www.esrl.noaa.gov/gmd/grad/ solcalc/calcdetails.html).

For the bottom layer (Fig. 2), two cases were distinguished. First, when bottom water was oxygenated and nychtemeral cycles were observed, Eq. (1) was modified with removal of the re-aeration term. The contribution of benthic respiration was lumped with the respiration of the bottom layer, as they could not be distinguished using only oxygen data.

Second, when bottom water was anoxic, there was no aerobic respiration and Eq. (1) could not be used. There must be anaerobic respiration, but that could not be easily quantified. In the ponds where anoxia was only transient, aerobic respiration did not stop completely, and a potential and average ER was calculated using decrease of oxygen concentration at the week scale after each overflow of river water above the dike and increase of dissolved oxygen concentration:

$E R=Z \cdot \frac{d\left[\mathrm{O}_{2}\right]}{d t}$

where $\mathrm{Z}$ is the depth of the water body (in $\mathrm{m}$ ).

\section{Results}

\subsection{Connectivity between ponds and the main river channel}

The ordering of ponds using the two methods of estimation of connectivity, namely based on dike height profiles and on temperature differences, are similar: from C3 the most isolated to C5 the most connected (Table 2). Different evaluations are obtained for C1 (Table 2), because of a slight porosity of the dike inducing an inflow of fresh river water and thus a high connectivity when the temperature is used.

\subsection{Biological and chemical classification of the ponds}

The two first axes of the MCA are retained for interpretation (Fig. 3). The first axis (28\% of variance) takes into account the lack of macrophytes $(r=0.68)$, the dominance of Dinoflagellae $(r=0.94)$, the 
Table 2

Degree of hydraulic connectivity of each pond with the river based either on dike geometry or on temperature difference between pond and river (increasing and decreasing with the connectivity, respectively). The ponds are ranked by increasing order of hydraulic connectivity.

\begin{tabular}{|c|c|c|c|c|c|c|}
\hline & $\mathrm{C} 3$ & $\mathrm{C} 2$ & $\mathrm{C} 4$ & $\mathrm{C} 1$ & C6 & C5 \\
\hline Connectivity w/river" (dike) & 0.31 & 0.44 & 0.47 & 0.48 & 1 & 1 \\
\hline Connectivity w/river ${ }^{*}(\Delta \mathrm{T})\left({ }^{\circ} \mathrm{C}\right)$ & 1.93 & 1.88 & 1.46 & 1.14 & 1.21 & 0.96 \\
\hline
\end{tabular}

density of phytoplanktonic cells $(\mathrm{r}=0.93)$, the $\mathrm{C}_{\mathrm{org}} /$ tot of the sediment $(\mathrm{r}=0.92)$ and the turbidity $(\mathrm{r}=0.67)$, while the second axis $(21 \%$ of variance) accounts for the dominance of Chrysophytes $(r=0.60)$, the nitrate $(r=0.45)$ and phosphate $(r=0.54)$ concentrations, the percentage of organic matter in the sediment $(r=0.51)$, and the hydrolasic activity of sediment biofilms $(r=0.46)$.

Three types of ponds can be defined on the basis of this MCA (Fig. 3): type I corresponds to C3, clearly distinct on the negative side of the first axis. This field is characterized by a weak diversity of phytoplankton but with a very high cell density of Dinoflagellates
(3400-5300 $10^{3}$ cells/L, Tables 3 and S1). Phytoplankton density limits light penetration $\left(Z_{\text {secchi }} / Z=45 \%\right)$, leading to turbid water and lack of macrophytes. Nutrient concentrations are low, especially for nitrates that totally disappear in association with anoxia. In the sediment, abundance $(\% \mathrm{OM})$ and quality $\left(\mathrm{C}_{\mathrm{org}} / \mathrm{N}_{\text {tot }}\right)$ of organic matter as well as hydrolysis activity (FDA activity) are high. C3 is almost eutrophic (24 $\mu \mathrm{g} \mathrm{chl} \mathrm{a/L} \mathrm{in} \mathrm{September} \mathrm{2014).}$

The next type (type II) gathers ponds showing a gradation in functioning. Ponds in this ensemble all have at least some macrophytes rooted in the sediment, due to relative transparency and penetration of light down to the bottom of the field $\left(Z_{\text {secchi }} / Z=87-100 \%\right)$. Nutrient and phytoplankton concentrations are intermediate. These ponds are oligo- to mesotrophic (chl a $<9 \mu \mathrm{g} / \mathrm{L})$. Ponds C2 and C4 have higher percentage of organic matter, slightly higher phosphate concentration and hydrolasic activity, while ponds $\mathrm{C} 1$ and $\mathrm{C} 6$ have lower organic matter and slightly higher nitrate contents.

The last type (type III) corresponds to C5, clearly distinct on the positive side of the second axis. It is very turbid $\left(\mathrm{Z}_{\text {secchi }} / \mathrm{Z} \sim 60 \%\right)$, with limited development of macrophytes and phytoplankton. Among all ponds, C126 is the only system to be dominated by large size colonies of Chrysophytes (of the genus Dinobryon, Table 3). The sediment is quite

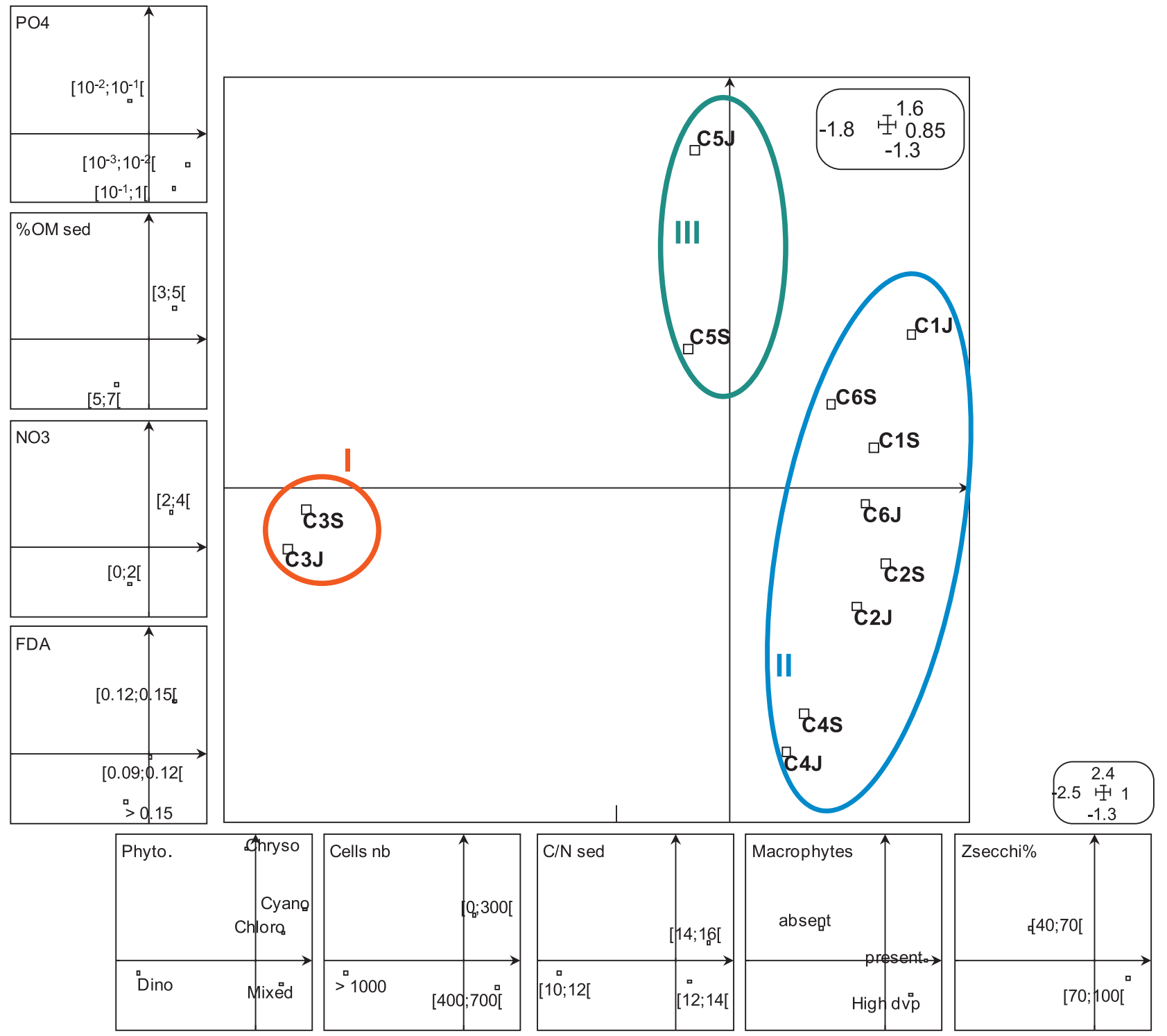

Fig. 3. Multiple Correspondence Analysis of the chemical and biological data with individual factor map of each pond sampling along the first two axes and factor maps for the 9 analyzed chemical and biological variables. See text for details. The three types of ponds (I, II, III) are underlined in the MCA factor map. 
Table 3

Concentrations of the most abundant phytoplanktonic species sampled in the 6 ponds, expressed in number of cell/L.

\begin{tabular}{|c|c|c|c|c|c|c|c|c|c|}
\hline & Dino & Cyano & Cyano & Chloro & Euglen & Chloro & Chryso & Chloro & Dino \\
\hline & Ceratium hirundinella & Limnothrix $s p$ & Oscillatoria sp. & Pandorina morum & Euglena spirogyra & Cladophora sp. & Dinobryon divergens & Spirogyra varians & Peridinium cinctum \\
\hline $\mathrm{C} 1$ & & & $1.2610^{5}$ & $6.8510^{4}$ & & & & & \\
\hline $\mathrm{C} 2$ & & & $7.7710^{4}$ & $1.9010^{4}$ & & & $2.5410^{4}$ & & \\
\hline $\mathrm{C} 3$ & $1.3410^{6}$ & & & & & & & & \\
\hline $\mathrm{C} 4$ & & $2.0410^{4}$ & & & $2.4810^{4}$ & & & & \\
\hline $\mathrm{C} 5$ & & & & & & & $2.2210^{4}$ & $1.2810^{4}$ & $1.2610^{4}$ \\
\hline $\mathrm{C} 6$ & & & & $4.2710^{3}$ & & $5.6010^{3}$ & & & \\
\hline
\end{tabular}

poor in organic matter, with high $\mathrm{C} / \mathrm{N}$ (varying between 13 and 15, low degradability), and the water with intermediate concentrations in nitrates and phosphates. C5 is mesotrophic ( $9 \mu \mathrm{g} \mathrm{chl} \mathrm{a/L} \mathrm{in} \mathrm{September}$ 2014).

\subsection{Metabolism of ponds}

All ponds exhibit vertical thermal and chemical (oxygen) stratification, but spatial heterogeneity is observed from one pond to the other. In all ponds, temperature time series clearly indicate marked nychtemeral cycles at the surface, strongly dampened and slightly lagged at the bottom, corresponding to diffusion of heat in the water column. In ponds $\mathrm{C} 1, \mathrm{C} 4$ and $\mathrm{C} 6$, there are limited temperature differences between the surface and bottom layers, while in fields C3 and C5 temperature at the bottom is strongly attenuated, up to $4{ }^{\circ} \mathrm{C}$ colder (Supplement Fig. S2). The field C2 has an intermediate behavior with temperature attenuation in August and similar cycling at surface and depth during autumn.

Similar nychtemeral cycles are observed for oxygen concentration at the surface (Fig. 4). Oxygen concentrations at the bottom are similar to those at the surface in C1, C6 and C4, while anoxia occurs during most of studied period in C3 (even reaching surface water) and, in a lesser extent, in C5. Finally in C2, the duration of anoxia at the bottom is intermediate.

In ponds $\mathrm{C} 1$ and $\mathrm{C} 6$, GPP and ER values are low with a low variability during all the studied period (Fig. 5), leading to a slight negative NEP value. In contrast, in ponds C3, C2, C4 and C5, GPP and ER are more intense with a large variability from August to mid-October and then decreased in intensity coupled with a lower variability in November during the floods (Fig. 5).

In this group, the pond C3 is characterized by large GPP (mean of $7.6 \mathrm{gO}_{2} \mathrm{~m}^{-2}$ day ${ }^{-1}$, Table 4) and very large ER (mean of $-10.3 \mathrm{gO}_{2}$ $\mathrm{m}^{-2}$ day $^{-1}$, Table 4) in the surface layer and no GPP and ER in the bottom layer (but most probably anaerobic respiration). This results in a negative NEP value $\left(-2.8 \mathrm{gO}_{2} \mathrm{~m}^{-2}\right.$ day $\left.^{-1}\right)$. In contrast, the surface layers of the ponds $\mathrm{C} 2, \mathrm{C} 4$ and $\mathrm{C} 5$ are characterized by intermediate values of GPP (from 5.7 to $6.3 \mathrm{gO}_{2} \mathrm{~m}^{-2}$ day $^{-1}$ ) and of ER ( -6.0 to $-7.0 \mathrm{gO}_{2} \mathrm{~m}^{-2}$ day $^{-1}$ ), resulting in slightly negative values of NEP, close to the equilibrium (from -0.2 to $-0.7 \mathrm{gO}_{2} \mathrm{~m}^{-2} \mathrm{day}^{-1}$ ). In the ponds $\mathrm{C} 2$ and $\mathrm{C} 5$, respiration induced anoxia in the bottom layer that prevents GPP and ER calculations, while in the pond C4 the oxygen reaches the bottom layer resulting, in large GPP and ER values (Table 4).

\section{Discussion}

\subsection{Functional classification viewed from biochemistry and hydraulic connectivity}

Our results highlight a large variability in the functioning of these artificial ecosystems. A typology of the ponds is presented as a function of hydraulic connectivity. We recognize 3 types of ponds, whose functions can be compared with functions of "natural" ecosystems (Fig. 6).
Type I has a marsh like functioning with organic-rich and stagnant water bodies (Grasset et al., 2017, López-Archilla et al., 2004). It appears to be mainly isolated from the river, with large amount of phytoplankton and marked eutrophication. The nutrient inflow is or should have been high, allowing significant amount of phytoplankton biomass to grow, but leading to quite low concentrations of phosphate and ammonium. The large concentration of phytoplankton cells leads to a high turbidity in the bottom layer, hence preventing the development of macrophytes. Sedimentation of dead phytoplankton cells leads to large quantity of organic matter of variable quality, strong mineralization, and more or less permanent anoxia at the bottom. This setting favors the occurrence of denitrification processes at the bottom of the pond, with total removal of nitrate.

On the opposite, type III is strongly connected to the river, with intermediate chlorophyll a and nutrient concentrations but significant turbidity linked to suspended material, altogether preventing the development of macrophytes. This pond is characterized by rather well oxygenated surface layer due to a photosynthetic activity. In the bottom layer, turbidity prevents any photosynthetic activity and anoxia regularly builds up, but with no indication of denitrification. This type of artificial wetland is characterized by a functioning similar to abandoned river channels or alluvial plain backwater (Castella et al., 2015).

Finally, type II gathers ponds where the water column is clear enough for macrophytes to root and develop, therefore leading to at least some oxygenation of the bottom layer ( $\mathrm{C} 2, \mathrm{C} 4, \mathrm{C} 1, \mathrm{C} 6)$. These ponds look like aquariums. Higher concentrations of phosphate and/or ammonium can be observed, even though mineralization of organic matter remains limited, and are thus probably due to low productivity of macrophytes and low consumption of nutrients, assuming a similar input of nutrients for all ponds. This group consists in a gradient of ponds with a range of trophic states: $\mathrm{C} 6$ and $\mathrm{C} 1$ are oligotrophic water bodies with limited amount of organic matter in the sediment, while C2 and C4 are mesotrophic water bodies with higher amount of organic matter in the sediment. This gradient in trophic state mirrors the gradient of connectivity to the river, with permanent connection in $\mathrm{C} 6$ and porous dike in $\mathrm{C} 1$, but less frequent connections by overflow in $\mathrm{C} 2$ and C4. This type of pond with clear water and well developed macrophytes are frequently found in gravel pits or oxbow lakes fed by oligotrophic groundwater (e.g. Jeppesen et al., 2016; Søndergaard et al., 2018).

\subsection{From strong to weak metabolism in stratified artificial wetlands}

The orders of magnitude of metabolism obtained for the ponds are similar to values determined from oxygen data in shallow lakes by López-Archilla et al. (2004). All ponds have negative NEP values, thus are heterotrophic.

Thermal and chemical stratification is observed with variable intensity in all ponds, even though it was not expected for such shallow depths. The strongest stratification is observed in ponds with the largest turbidity. When associated with strong metabolism intensity, stratification can lead to anoxia in the bottom layer, anaerobic processes such as denitrification replacing aerobic respiration.

In all ponds, the temporal variability of metabolism appears to be 


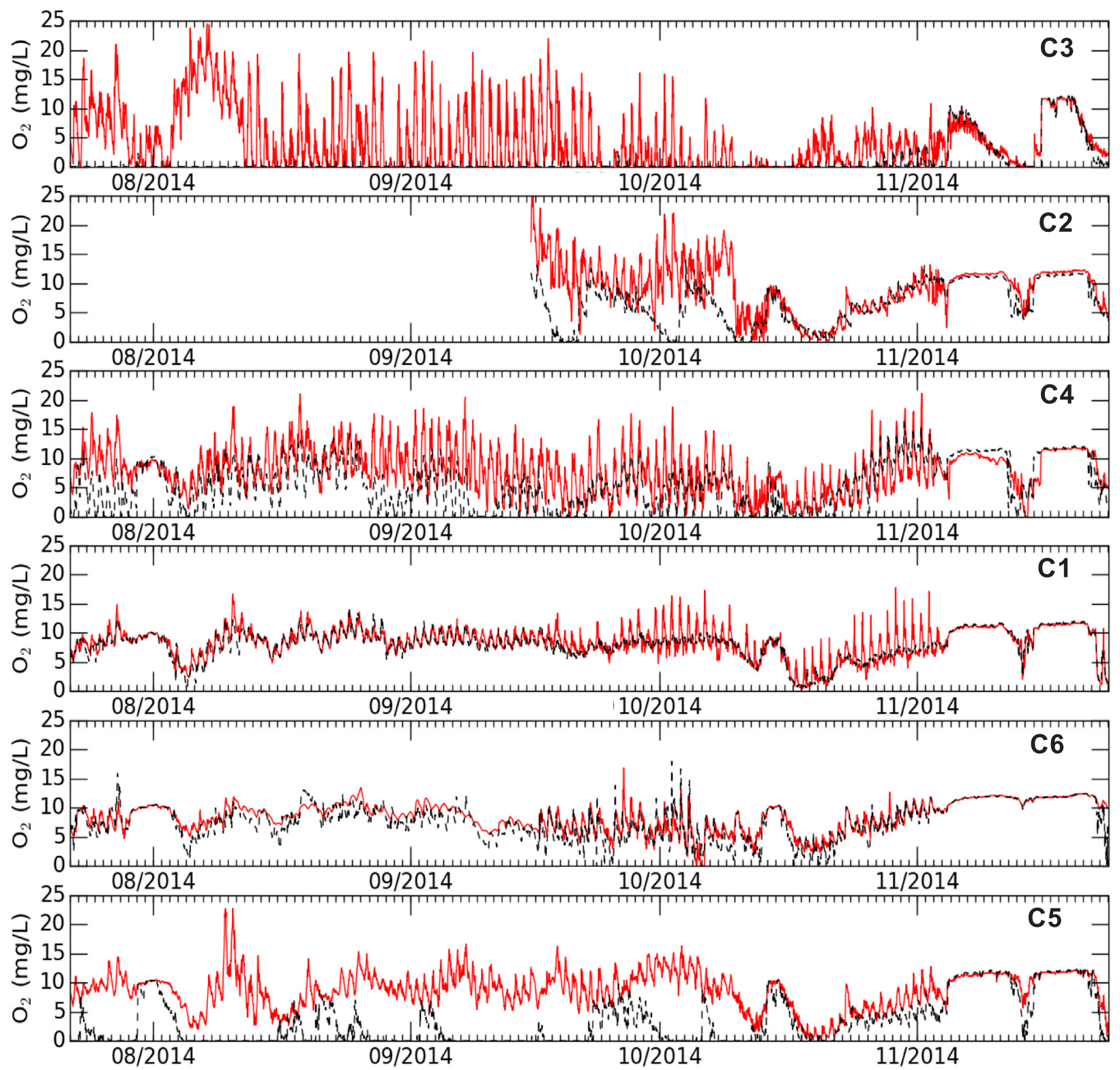

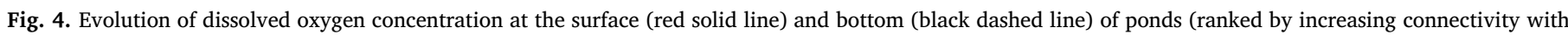
the river).

important, with decreasing intensity in autumn due to floods that homogenizes the vertical gradients. The impact of nutrients inflow during floods on ecosystem productivity, as emphasized by the Flood Pulse Concept (Junk, 2005) is thus not clearly visible here for the ponds. The spatial variability between ponds is even higher than temporal variability, with a range of metabolism intensity from the weakest (C6) to the strongest (C3).

\subsection{Comparison between metabolism approach and biological and chemical classification}

The gradient of metabolism intensity between ponds can be compared to the gradient established based on the chemical and biological characteristics and connectivity. The two gradients are consistent, even if, depending on the situation, one approach can bring specific information. The comparison is done below by order of increasing connectivity with the river.

The metabolism in the most isolated pond C3 is different from the other sites, with very large values of GPP and ER, and the largest negative NEP values indicating heterotrophy. These metabolism values are consistent with the highest number of cells, highest concentration in chl a, quite low phosphate and ammonium concentrations, and lowest $\mathrm{C} / \mathrm{N}$ (good quality of organic matter in the sediment). The large values of GPP and ER are linked to a dominance of phytoplankton that prohibits the development of macrophytes. The dominant taxa are mostly Dinoflagellates (Table 3), with mixotrophic organisms that can turn to organic matter consumption when light inflow becomes limited (Reynolds et al., 2002; Salmaso and Padisák, 2007; Smalley and Coats, 2002).

C1 and C6 are both connected through an opening or porosity of the dike, and show low intensity of metabolism. This is linked to a low amount of phytoplankton, and the presence of large amount of macrophytes in clear water, oxygenated at the bottom. The NEP is weakly negative, indicating recycling of organic matter close to equilibrium. For these three ponds, the classification from chemical and biological parameters and connectivity is thus fully consistent with metabolism. In 
C3
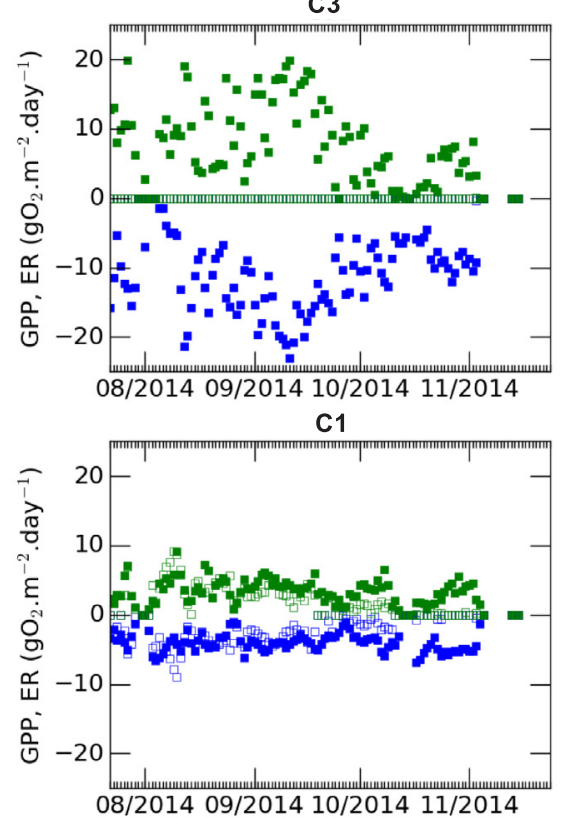

C2

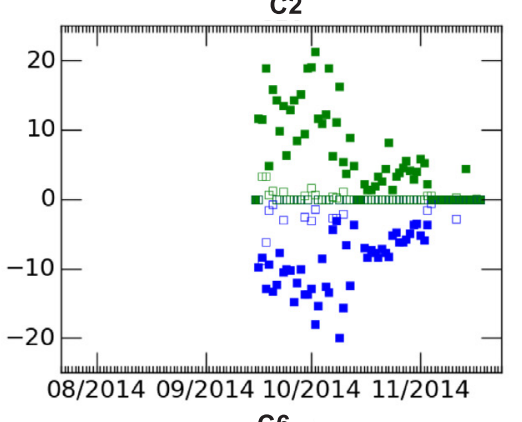

C6

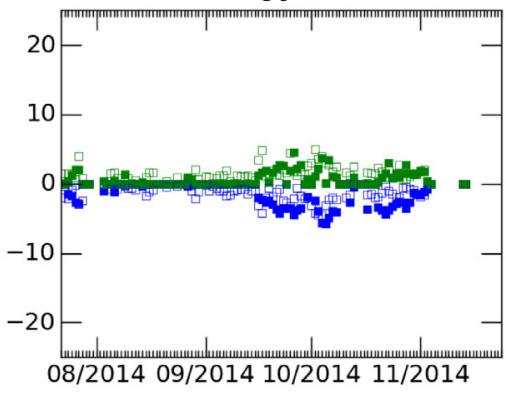

C4

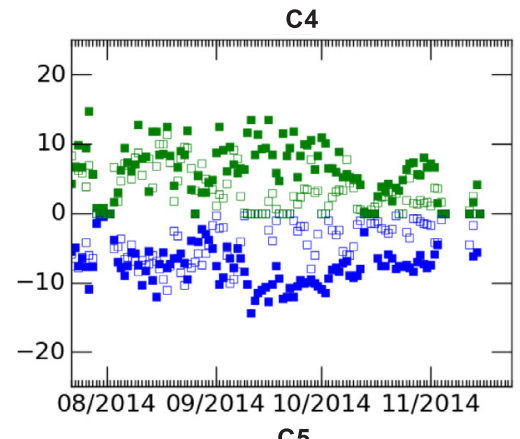

C5

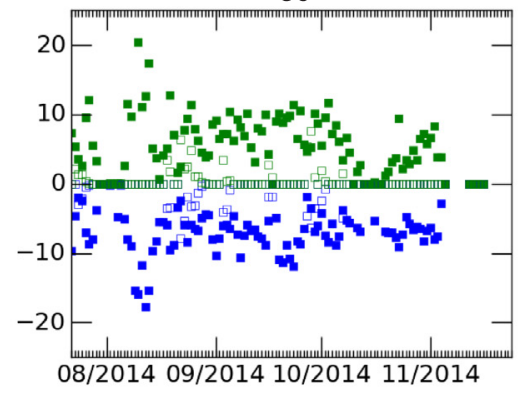

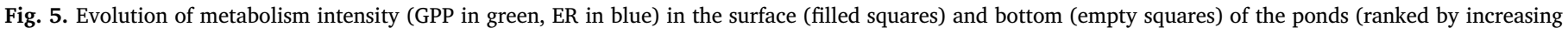
connectivity with the river).

contrast, the last three ponds show more complex relations between chemical and biological parameters, connectivity and metabolism.

Ponds C2 and C4 have intermediate connectivity with the main channel, and similar metabolism and chemical and biological characteristics in the surface layer. GPP and ER values at the surface are intermediate, in agreement with intermediate phytoplankton density and presence of macrophytes (especially in C4), and mesotrophic trophic state. Nutrients concentrations are quite variable in space and time, and cannot be not directly correlated with metabolism intensity, even if a homogeneous input is assumed. Higher phosphate concentration in C4 could be due to a lower productivity of macrophytes compared to phytoplankton, even though to the GPP value is intermediate. For the bottom layer, differences occur between these two ponds: the less connected C2 shows longer anoxic events than C4. In this case, metabolism analysis brings more details and consistency with connectivity than chemical and biological parameters.

Finally, in widely open pond C5, the calculated intermediate values of metabolism would tend to group it with $\mathrm{C} 2$, while chemical and biological characteristics and connectivity make it clearly different. C5 is well connected to the main channel of the Rhône River, with regular inflows of surface water and strong increase in turbidity. This induces long periods of anoxia at the bottom, low phytoplankton and no macrophytes. Anaerobic processes must occur at the bottom, but cannot be evidenced by nitrate concentration. The large values of GPP and ER at the surface may be due to physical oxygenation due to water inflow from the main channel (connectivity value of 1 ) or biological production because of the large colony size and high photosynthetic productivity of the dominant species, Dinobryon. In this case, biological characteristics are more efficient than metabolism measures to explain alluvial system functioning.

\subsection{Consequences for restoration plans}

The proposed functional typology of the artificial alluvial ponds ranges from clear aquarium-like water bodies with variable amounts of macrophytes, to turbid backwaters or marshes with large amounts of phytoplankton and no macrophytes.

The equilibrium between macrophytes and phytoplankton, reported for shallow lakes (Scheffer et al., 1993; Scheffer and Jeppesen, 2007), and in floodplains water bodies (Amoros and Bornette, 2002), depends on water turbidity and on the capacity of macrophytes to root at the bottom of the water body. This thus depends on the interactions between water residence time (hence degree of hydraulic connectivity with the river), sedimentation rate and depth of the pond (Cheng and Basu, 2017). In aquarium-type ponds with small sedimentation rates and short sedimentation times, phytoplankton has less time to develop before macrophytes development, and the water remains clear. On the opposite, for longer sedimentation times and higher sedimentation rates in marsh or backwater type ponds, conditions become favorable for phytoplankton that will then inhibit macrophytes.

Connectivity between the floodplain and the river is thus crucial for large river productivity, but as underlined by Junk (2005), flood-

Table 4

Average intensity of daily metabolism calculated for the surface and bottom of the 6 ponds (ranked by increasing connectivity with the river), along with standard deviation. The ER bottom values for C2, C3 and C5 were estimated for anoxic conditions. See text for details.

\begin{tabular}{|c|c|c|c|c|c|c|}
\hline \multirow[t]{2}{*}{ Pond } & \multicolumn{3}{|c|}{ Surface $\left(\mathrm{g} \mathrm{O}_{2} \mathrm{~m}^{-2}\right.$ day $\left.^{-1}\right)$} & \multicolumn{3}{|c|}{ Bottom $\left(\mathrm{g} \mathrm{O}_{2} \mathrm{~m}^{-2}\right.$ day $\left.^{-1}\right)$} \\
\hline & GPP & ER & NEP & GPP & ER & NEP \\
\hline C3 & $7.6 \pm 5.9$ & $-10.3 \pm 5.7$ & $-2.8 \pm 3.4$ & & $-1.8 \pm 1.1$ & \\
\hline $\mathrm{C} 2$ & $6.3 \pm 6.2$ & $-6.6 \pm 5.4$ & $-0.3 \pm 3.4$ & & $-2.6 \pm 1.5$ & \\
\hline $\mathrm{C} 4$ & $6.3 \pm 3.7$ & $-7.0 \pm 3.4$ & $-0.7 \pm 2.1$ & $3.4 \pm 3.1$ & $-3.5 \pm 3.0$ & $-0.1 \pm 1.1$ \\
\hline $\mathrm{C} 1$ & $3.2 \pm 1.9$ & $-3.6 \pm 1.7$ & $-0.4 \pm 1.6$ & $2.0 \pm 2.0$ & $-2.0 \pm 2.0$ & $0.0 \pm 0.7$ \\
\hline C6 & $0.7 \pm 0.7$ & $-1.2 \pm 1.2$ & $-0.5 \pm 1.1$ & $1.2 \pm 1.1$ & $-1.2 \pm 1.1$ & $0.0 \pm 0.5$ \\
\hline C5 & $5.7 \pm 4.6$ & $-6.0 \pm 3.8$ & $-0.3 \pm 2.6$ & & $-4.0 \pm 1.4$ & \\
\hline
\end{tabular}




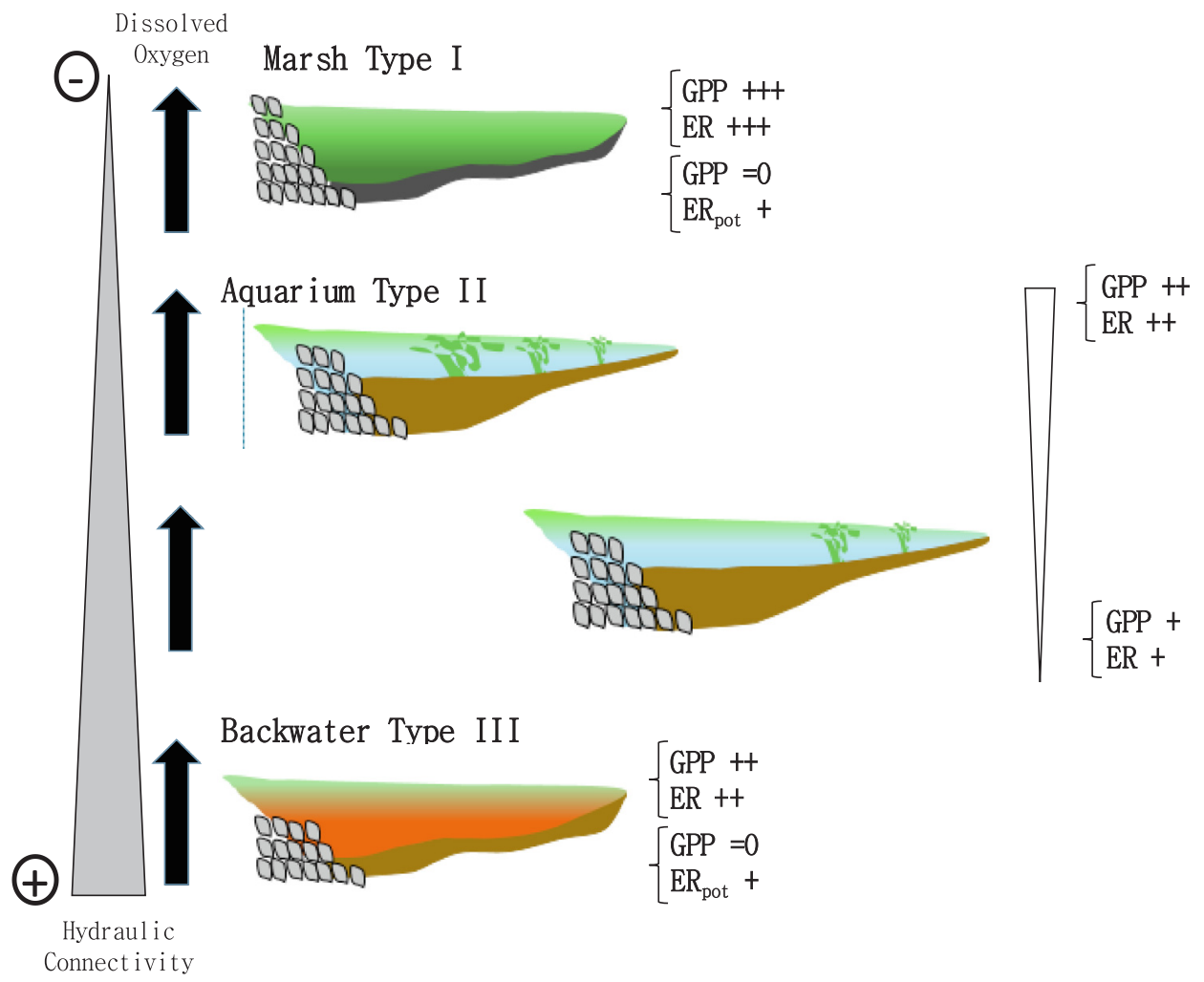

Fig. 6. Representation of the three types of ponds: from poorly connected marsh (top) with a lot of phytoplankton (represented in green), to highly connected backwater (bottom) with high concentration of suspended matter (represented in brown). Ponds having clear water like aquarium, and macrophytes, are along a gradient of connectivity.

Connectivity

induced interactions are complex with respect to hydrology, geomorphology, biota ecology, and biogeochemical cycles. This complexity is shown here to be of major importance during the low water period, and, besides productivity, the diversity of ponds must be taken into account for restoration plans, especially regarding their connectivity with the channel. Isolated marshes, open backwaters and clear aquarium-like water bodies have to coexist, in order to support a large habitat diversity and potential large biodiversity at the scale of the alluvial plain. For example, the diversity of wetlands associated to the Rhône River in the Brégnier-Cordon sector hosts a large diversity of fishes with contrasted biological traits (Copp, 1989). In the same way, dragonflies' diversity is widely controlled by habitat heterogeneity (Castella et al., 2015).

The connectivity of ponds and dike fields with the main channel is also an essential tool for restoration plans. Intermediate connectivity maintains an intermediate water and nutrient residence time and a diversity of habitats at the scale of a single pond. A way to maintain such an intermediate residence time is to connect adjacent dike fields to each other in order to increase the flow of water, without direct input of turbid water from the Rhône River (Thorel et al., 2018).

\section{Conclusion}

The understanding and information brought by hydraulic connectivity with the river, chemical and biological characteristics of the water bodies and continuous monitoring of dissolved oxygen and associated metabolism modeling, appear to be consistent and highly complementary. Connectivity and chemical and biological parameters allow to distinguish phytoplankton and macrophytes roles, while metabolism allow identification of transient evolutions, vertical stratification and productivity of the primary producers. These approaches thus need to be combined to build a comprehensive understanding of this ecosystem functioning.

In the future, the consequences of the functional diversity of the ponds on the microbial and phytoplanktonic diversity will have to be considered. Metabolism modeling in artificial wetlands could also help understanding connections with other water bodies such as groundwater or tributaries.

\section{Acknowledgments}

This work was funded by Zone Atelier Bassin du Rhône (action $\mathrm{n}^{\circ} 41$ ), the Observatoire Hommes- Milieux Vallée du Rhône (OHMVR) and the Rhône-Méditerranée Water Agency. We thank the Compagnie Nationale du Rhône (CNR) for providing discharge data for the Rhône. The PIREN-Seine research program and the Zone Atelier Seine are acknowledged for their support. We thank the two anonymous reviewers for their comments that helped increasing the quality of the manuscript.

\section{Appendix A. Supplementary data}

Supplementary data to this article can be found online at https:// doi.org/10.1016/j.ecoleng.2018.12.018.

\section{References}

Amoros, C., Bornette, G., 2002. Connectivity and biocomplexity in waterbodies of riverine floodplains. Freshw. Biol. 47, 761-776.

Battin, T.J., 1997. Assessment of fluorescein diacetate hydrolysis as a measure of total esterase activity in natural stream sediment biofilms. Sci. Total Environ. 198, 51-60.

Castella, E., Béguin, O., Besacier-Monbertrand, A.L., Hug Peter, D., Lamouroux, N., Mayor Siméant, H., McCrae, D., Olivier, J.M., Paillex, A., 2015. Realised and predicted changes in the invertebrate benthos after restoration of connectivity to the floodplain of a large river. Freshw. Biol. 60, 1131-1146.

Cheng, F.Y., Basu, N.B., 2017. Biogeochemical hotspots: Role of small water bodies in landscape nutrient processing. Water Resour. Res. 53, 5038-5056.

Cole, J.J., Caraco, N.F., 1998. Atmospheric exchange of carbon dioxide in a low-wind oligotrophic lake measured by the addition of SF6. Limnol. Oceanogr. 43, 647-656.

Coloso, J.J., Cole, J.J., Hanson, P.C., Pace, M.L., 2008. Depth-integrated, continuous estimates of metabolism in a clear-water lake. Can. J. Fish. Aquat. Sci. 65, 712-722.

Copp, G.H., 1989. The habitat diversity and fish reproductive function of floodplain ecosystems. Environ. Biol. Fishes 26, 1-27.

Cox, B.A., 2003. A review of dissolved oxygen modelling techniques for lowland rivers. Sci. Total Environ. 314, 303-334.

Cronk, J.K., Mitsch, W.J., 1994. Aquatic metabolism in four newly constructed freshwater wetlands with different hydrologic inputs. Ecol Eng. 3, 449-468.

Davidson, N.C., 2014. How much wetland has the world lost? Long-term and recent 
trends in global wetland area. Mar. Freshw. Res. 65, 934-941.

Džubáková, K., Piégay, H., Riquier, J., Trizna, M., 2015. Multi-scale assessment of overflow-driven lateral connectivity in floodplain and backwater channels using LiDAR imagery. Hydrol. Process. 29, 2315-2330.

Erwin, S.O., Jacobson, R.B., Elliott, C.M., 2017. Quantifying habitat benefits of channel reconfigurations on a highly regulated river system, Lower Missouri River, USA. Ecol Eng. 103, 59-75.

Escoffier, N., Bensoussan, N., Vilmin, L., Flipo, N., Rocher, V., David, A., Métivier, F., Groleau, A., 2018. Estimating ecosystem metabolism from continuous multi-sensor measurements in the Seine River. Environ. Sci. Pollut. Res. 25, 23451-23467.

Español, C., Gallardo, B., Comín, F.A., Pino, M.R., 2015. Constructed wetlands increase the taxonomic and functional diversity of a degraded floodplain. Aquat. Sci. 77 , $27-44$.

Fontvieille, D., Outaguerouine, A., Thevenot, D., 1992. Fluorescein diacetate hydrolysis as a measure of microbial activity in aquatic systems: application to activated sludges. Environ Technol. 13, 531-540.

Ford, P.W., Boon, P.I., Lee, K., 2002. Methane and oxygen dynamics in a shallow floodplain lake: the significance of periodic stratification. Hydrobiologia 485, 97-110.

Franquet, E., Cellot, B., Pont, D., Bournaud, M., 1995. Environmental and macroinvertebrate dynamics in the Lower Rhône River and a lateral dike field: a study matching two functioning descriptors. Hydrobiologia 308, 207-217.

Gibbs, J.P., 2000. Wetland loss and biodiversity conservation. Conserv. Biol. 14, 314-317.

Grasset, C., Rodriguez, C., Delolme, C., Marmonier, P., Bornette, G., 2017. Can soil organic carbon fractions be used as functional indicators of wetlands? Wetlands. 1-11.

Hansson, L.A., Brönmark, C., Nilsson, P.A., Åbjörnsson, K., 2005. Conflicting demands on wetland ecosystem services: Nutrient retention, biodiversity or both? Freshw. Biol. 50, 705-714.

Jeppesen, E., Trolle, D., Davidson, T.A., Bjerring, R., Søndergaard, M., Johansson, L.S., Lauridsen, T.L., Nielsen, A., Larsen, S.E., Meerhoff, M., 2016. Major changes in CO2 efflux when shallow lakes shift from a turbid to a clear water state. Hydrobiologia 778, 33-44.

Junk, W.J., Bayley, P.B., Sparks, R.E., 1989. The flood pulse concept in river-floodplain systems. In: Dodge, D.P. (Ed.), International Large River Symposium: Can. Spec. Pub. Fish. Aqu. Sc. pp. 110-127.

Junk, W.J., 2005. Flood pulsing and the linkages between terrestrial, aquatic, and wetland systems. SIL Proceedings 1922-2010 (29), 11-38.

Koontz, M., Lundberg, C., Lane, R., Day, J., Pezeshki, R., 2016. Aboveground net primary productivity in a riparian wetland following restoration of hydrology. Biology. 5.

Lane, R.R., Mack, S.K., Day, J.W., Kempka, R., Brady, L.J., 2017. Carbon sequestration at a forested wetland receiving treated municipal effluent. Wetlands. 37, 861-873.

López-Archilla, A.I., Mollá, S., Coleto, M.C., Guerrero, M.C., Montes, C., 2004. Ecosystem metabolism in a mediterranean shallow lake (Laguna de Santa Olalla, Doñana National Park, SW Spain). Wetlands 24, 848-858.

Mermillod-Blondin, F., Foulquier, A., Maazouzi, C., Navel, S., Negrutiu, Y., Vienney, A., Simon, L., Marmonier, P., 2013. Ecological assessment of groundwater trophic status by using artificial substrates to monitor biofilm growth and activity. Ecol. Ind. 25, 230-238.

Millennium Ecosystem Assessment, 2005. Ecosystems and Human Well-being: Wetlands and Water. Synthesis. World Resources Institute, Washington, DC.

Mitsch, W.J., Gossilink, J.G., 2000. The value of wetlands: Importance of scale and landscape setting. Ecol. Econ. 35, 25-33.

Mitsch, W.J., Bernal, B., Nahlik, A.M., Mander, Ü., Zhang, L., Anderson, C.J., Jørgensen, S.E., Brix, H., 2013. Wetlands, carbon, and climate change. Landscape Ecol. 28, 583-597.

Moore, T.R., Roulet, N.T., Waddington, J.M., 1998. Uncertainty in predicting the effect of climatic change on the carbon cycling of Canadian peatlands. Clim. Change 40, 229-245.

Needoba, J.A., Peterson, T.D., Johnson, K.S., 2012. Method for the quantification of aquatic primary production and net ecosystem metabolism using in situ dissolved oxygen sensors. In: Tiquia-Arashiro, S.M. (Ed.), Molecular Biological Technologies for Ocean Sensing. Springer, New York, pp. 73-101.

Nicolas, Y., Pont, D., 1997. Hydrosedimentary classification of natural and engineered backwaters of a large river, the lower Rhône: possible applications for the maintenance of high fish biodiversity. Regulated Rivers: Res. Manag. 13, 417-431.

Odum, H.T., 1956. Primary production in flowing waters. Limnol. Oceanogr. 1, 102-117.

Paillex, A., Dolédec, S., Castella, E., Mérigoux, S., 2009. Large river floodplain restoration: Predicting species richness and trait responses to the restoration of hydrological connectivity. J. Appl. Ecol. 46, 250-258.

Pont, D., Day, J.W., Ibáñez, C., 2017. The impact of two large floods (1993-1994) on sediment deposition in the Rhône delta: Implications for sustainable management. Sci. Total Environ. 609, 251-262.

Preiner, S., Drozdowski, I., Schagerl, M., Schiemer, F., Hein, T., 2008. The significance of side-arm connectivity for carbon dynamics of the River Danube, Austria. Freshwater Biol. 53, 238-252.

Reeder, B.C., Binion, B.M., 2001. Comparison of methods to assess water column primary production in wetlands. Ecol. Eng. 17, 445-449.

Reynolds, C.S., Huszar, V., Kruk, C., Naselli-Flores, L., Melo, S., 2002. Towards a functional classification of the freshwater phytoplankton. J. Plankton Res. 24, 417-428.

Salmaso, N., Padisák, J., 2007. Morpho-Functional Groups and phytoplankton development in two deep lakes (Lake Garda, Italy and Lake Stechlin, Germany). Hydrobiologia 578, 97-112.

Scheffer, M., Hosper, S.H., Meijer, M.L., Moss, B., Jeppesen, E., 1993. Alternative equilibria in shallow lakes. Trends Ecol. Evol. 8, 275-279.

Scheffer, M., Jeppesen, E., 2007. Regime shifts in shallow lakes. Ecosystems 10, 1-3.

Smalley, G.W., Coats, D.W., 2002. Ecology of the red-tide dinoflagellate Ceratium furca: Distribution, mixotrophy, and grazing impact on ciliate populations of Chesapeake Bay. J. Eukaryotic Microbiol. 49, 63-73.

Søndergaard, M., Lauridsen, T.L., Johansson, L.S., Jeppesen, E., 2018. Gravel pit lakes in Denmark: Chemical and biological state. Sci. Total Environ. 612, 9-17.

Staehr, P.A., Bade, D., Van de Bogert, M.C., Koch, G.R., Williamson, C., Hanson, P., Cole, J.J., Kratz, T., 2010. Lake metabolism and the diel oxygen technique: State of the science. Limnol. Oceanogr.-Methods 8, 628-644.

Tenenhaus, M., Young, F.W., 1985. An analysis and synthesis of multiple correspondence analysis, optimal scaling, dual scaling, homogeneity analysis and other methods for quantifying categorical multivariate data. Psychometrika 50, 91-119.

Thorel, M., Piégay, H., Barthelemy, C., Räpple, B., Gruel, C.-R., Marmonier, P., Winiarski, T., Bedell, J.-P., Arnaud, F., Roux, G., Stella, J.C., Seignemartin, G., Tena-Pagan, A., Wawrzyniak, V., Roux-Michollet, D., Oursel, B., Fayolle, S., Bertrand, C., Franquet, E., 2018. Socio-environmental implications of process-based restoration strategies in large rivers: should we remove novel ecosystems along the Rhône (France)? Reg. Environ. Change. https://doi.org/10.1007/s10113-018-1325-7.

Tockner, K., Stanford, J.A., 2002. Riverine flood plains: Present state and future trends. Environ. Conserv. 29, 308-330.

Utermohl, H., 1958. Zur Vervollkommung der quantitativen Phytoplankton Mitteilung. Internationale Vereinigung Für Theoretische und Amgewandte Limnologie. 9, 1-38.

Vannote, R.L., Minshall, G.W., Cummins, K.W., Sedell, J.R., Cushing, C.E., 1980. The river continuum concept. Can. J. Fish. Aquat. Sci. 37, 130-137.

Wanninkhof, R., 1992. Relationship between wind speed and gas exchange over the ocean. J. Geophys. Res. 97, 7373-7382.

Welti, N., Bondar-Kunze, E., Tritthart, M., Pinay, G., Hein, T., 2012. Nitrogen dynamics in complex Danube River floodplain systems: effects of restoration. River Systems. 20, 71-85.

Whiting, G.J., Chanton, J.P., 2001. Greenhouse carbon balance of wetlands: Methane emission versus carbon sequestration. Tellus, Series B: Chem. Phys. Meteorol. 53, $521-528$. 